\title{
PERLINDUNGAN KONSUMEN TERHADAP TINDAKAN PEMADAMAN LISTRIK YANG DILAKUKAN SECARA SEPIHAK OLEH PT. PLN (PERSERO) UP3 BALI SELATAN
}

\author{
I Gede Dharma Kusuma, I Nyoman Putu Budiartha, Ida Ayu Putu Widiati \\ Fakultas Hukum, Universitas Warmadewa, Denpasar-Bali, Indonesia \\ budiarthaputu59@gmail.com
}

\begin{abstract}
Abstrak
Keadaan yang membuat masyarakat mengeluh terhadap pelayanan yang diberikan pihak PLN yaitu pemadaman listrik tanpa pemberitahuan terlebih dahulu. Banyaknya keluhan masyarakat berkaitan dengan pemadaman listrik membuat pihak PLN ke limpungan dalam membenahi struktur organisasi terutama di area sektor koordinasi antar pekerja. Tujuan penelitian ini untuk mengungkap pengaturan perlindungan hukum konsurnen pengguna listrik pada PT. PLN (Persero) UP3 serta upaya hukum yang dapat dilakukan oleh konsumen pengguna listrik apabila terjadi pemadaman listrik secara sepihak oleh PT. PLN Persero UP3 Bali Selatan. Metode penelitian ini menggunakan metode empiris dengan pendekatan perundang-undangan dan pendekatan kasus. Teknik pengumpulan data dilakukan dengan cara penelitian ke lapangan dengan menerapkan metode wawancara. Sumber data yang digunakan berupa sumber data primer dan sekunder. Teknik analisis data dilakukan secara sistematis. Hasil penelitian mengungkapkan pemerintah dalam hal memberikan perlindungan kepada masyarakat untuk mendapatkan pasokan listrik cukup membuat peraturan perlindungan konsumen yang didalamnya terdapat hak dan kewajiban konsumen untuk mendapatkan keadilan dan berkewajiban melakukan himbauan dari pemerintah dalam upaya mencegah terjadinya tindak pidana sesuai dengan hukum positif yang berlaku di Indonesia. Pemerintah mengatasi para pekerja lapangan dari pihak PLN yang secara sengaja atau tidak disengaja tidak memberitahu masyarakat pemadaman listrik bergilir ini dan sudah seharusnya pihak PLN memberikan teguran bagi para pekerjanya yang tidak menjalankan perintah sesuai SOP yang berlaku di perusahaan.
\end{abstract}

Kata Kunci: Perlindungan Konsumen, Pemadaman Listrik, Bali Selatan

\begin{abstract}
Circumstances that make people complain about the services provided by PLN are power outages without prior notification. The number of public complaints related to power outages has forced PLN to be confused in fixing the organizational structure, especially in the coordination sector between workers. The purpose of this research is to reveal the legal protection arrangements for consumers of electricity users at PT. PLN (Persero) $U P 3$ as well as legal remedies that can be taken by consumers using electricity in the event of a power outage unilaterally by PT. PLN Persero UP3 South Bali. This research method uses an empirical method with a statutory approach and a case approach. Data collection techniques were carried out by means of field research by applying the interview method. Sources of data used in the form of primary and secondary data sources. The data analysis technique was carried out systematically. The results of the research reveal that the government in terms of providing protection to the public to obtain electricity supply is sufficient to make consumer protection regulations in which there are consumer rights and obligations to obtain justice and are obliged to make appeals from the government in an effort to prevent criminal acts in accordance with positive law in force in Indonesia. The government is dealing with field workers from PLN who intentionally or unintentionally do not notify the public of this rotating power outage and PLN should give a warning to its workers who do not carry out orders according to the SOPs applicable in the company.
\end{abstract}

Keywords: Consumer Protection, Power Outages, South Bali

\section{PENDAHULUAN}

Indonesia merupakan negara yang terdiri dari beberapa pulau dan setiap wilayah yang ada memerlukan tenaga listrik sebagai kebutuhan sehari-hari maupun kebutuhan jangka panjang, keadaan yang ada saat ini banyak masyarakat mengeluh terhadap pelayanan yang diberikan pihak PLN yaitu pemadaman listrik tanpa pemberitahuan terlebih dahulu. Banyaknya keluhan masyarakat berkaitan dengan pemadaman listrik membuat pihak PLN Kelimpungan dalam membenahi struktur organisasi terutama di area sektor koordinasi antar pekerja. Pemerintah dalam hal memberikan perlindungan 
kepada masyarakat dalam hal mendapatkan pasokan listrik cukup serta membuat peraturan perlindungan konsumen yang didalamnya terdapat hak dan kewajiban konsumen untuk mendapatkan keadilan dan berkewajiban melakukan himbauan dari pemerintah dalam upaya mencegah terjadinya tindak pidana sesuai dengan hukum positif yang berlaku di lndonesia (Az. Nasution, 2003).

Dalam memajukan perekonomian pemerintah menyiapkan lapangan pekerjaan kepada semua masyarakat namun tidak semua bisa bekerja di pemerintahan karena berbagai alasan salah satunya pendidikan minimal dan usia, semakin tua usia semakin tidak diterima seseorang untuk bekerja di perusahaan atau pemerintahan karena ada yang namanya fase produktif dan tidaknya seseorang. Namun tidak semua masyarakat Indonesia menyerah dengan keadaan beberapa diantara membuka usaha untuk bisa melanjutkan kegiatan yang dapat menghasilkan sesuatu untuk menghidupi dirinya dan keluarganya.

Dengan berkembangnya teknologi maka bukan dari sektor perekonomiannya saja yang berkembang melainkan dari segi koordinasi juga. Salah satu kesalahan di bidang komunikasi pihak PLN adalah salah komunikasi antara atasan dan pekerja lapangan berkaitan dengan peredaran listrik dimasyarakat. Kejadian ini membuat banyak orang merasa dirugikan karena tanpa pemberitahuan masyarakat yang bekerja tidak bisa bekerja penuh kerena terkendala pemadaman listrik dan sebagian besar masyarakat saat ini bekerja menggunakan laptop yang terkait antara satu dan lainnya.

Pekerjaan merupakan suatu keharusan yang harus dilakukan setiap manusia, tujuannya sendiri untuk memenuhi kebutuhan dirinya dan keluarganya jika sudah memiliki keluarga. Selain memenuhi kebutuhan pekerjaan juga membuat seseorang menambah wawasan dan pergaulan dengan orangorang baru yang ditemui di dunia kerja. Dengan bekerja, seseorang dapat menghilangkan penat yang dia dapat dilingkungan keluarganya dan sebagai wadah untuk meniti karir namun terkadang jika bekerja tidak sepenuh hati maka akan sering terjadi kesalahan terutama pada komunikasi, setiap orang berhak menentukan pilihannya untuk bekerja dan setiap pemimpin wajib mengetahui kinerja karyawan dan masalah yang dihadapi karyawannya agar tidak sampai merugikan orang lain terutama yang berkaitan dengan perusahaan (Abdullah, 2010).

Menurut Pasal 1620 KUHP, perjanjian kerja adalah hasil dari perjanjian antara pengusaha dan pekerja untuk membangun hubungan kerja, dimana karyawan majikan terikat satu sama lain selama periode tertentu untuk melakukan pekerjaan tertentu oleh mendapatkan upah tertentu sesuai konsepnya. Dengan adanya kontrak kerja ini, baik majikan mau pun pekerja tidak dapat memberikan perintah dan melakukan pekerjaan sewenang-wenang, tetapi harus sesuai dengan ketentuan kontrak kerja.

Dewasa ini banyak para pekerja yang meski sudah mendapatkan penghasilan dari perusahaan yang mempekerjakannya masih memiliki kekurangan dana untuk memenuhi kebutuhan hidupnya dan keluarganya. Berbagai alasan yang ada seperti apa yang dikerjakan tidak sesuai upah sampai tidak sesuai kemampuan namun tetap melakukan pekerjaan tersebut yang membuat pekerja tidak betah dalam bekerja. Semakin seseorang melakukan pekerjaan tidak dengan keikhlasan dan keinginan yang semakin berat dan susah pekerjaan yang dilakukan.

Banyaknya orang yang membutuhkan pekerjaan membuat persaingan di tempat kerja juga semakin ketat ditambah sedikitnya perusahaan yang membuka lowongan untuk para pekerja membuat banyak masyarakat yang menganggur sembari berharap adanya lowongan pekerjaan yang dibuka. Para pekerja yang sudah mendapat pekerjaan harus melakukan pekerjaan sebaik mungkin dan tidak melanggar SOP yang berlaku supaya mempertahankan jabatannya dan meminimalisir terjadinya pemutusan hubungan kerja. Meli hat peluang yang ada saat ini penjualan produk obral online menjadi sampingan tersendiri bagi beberapa orang tidak terkecuali para pekerja yang tidak lagi mendapatkan pekerjaan.

Bagi pihak masyarakat terjadinya pemadaman list rik merasa dirugikan karena mengganggu efektifitas kerja, membuang waktu menunggu listrik menyala untuk bisa melanjutkan pekerjaan dan meminta pertanggungjawaban dari pihak PLN agar masalah seperti ini tidak terulang lagi. Para pekerja yang sudah mendapat pekerjaan harus melakukan pekerjaan sebaik mungkin dan tidak melanggar SOP yang berlaku supaya mempertahankan jabatannya dan meminimalisir terjadinya pemutusan hubungan kerja. Namun terkadang sebaik apapun pekerjaan yang dilakukan ada saja ketidakcocokan antar sesama karyawan atau dengan pimpinan perusahaan membuat seorang karyawan harus banyak bersabar demi mempertahankan pekerjaan karena sulitnya saat ini mencari pekerjaan. 
Menurut Andrea (2016) apabila terjadi pemadaman listrik sepihak oleh PT PLN (Persero), maka langkah awal adalah dengan memberikan pengaduan kepada PT PLN (Persero). Namun bila hasil upaya awal tersebut dirasa masih kurang memuaskan, konsumen dapat mengambil upaya hukum yakni penyelesaian sengketa melalui pengadilan atau diluar pengadilan berdasarkan pilihan sukarela para pihak yang bersengketa. Pada dasarnya perlindungan hukum telah diatur dalam Undang-undang No. 8 tahun 1999 tentang perlindungan konsumen dimaksudkan untuk menjadi landasan hukum yang kuat bagi pemerintah dan lembaga perlndungan konsumen (Ardiyati \& Hartono, 2019). Hak konsumen listrik berupa hak untuk mendapat pelayanan yang baik, tenaga listrik secara terus-menerus dengan mutu dan keandalan yang baik dengan harga yang wajar, pelayanan untuk perbaikan apabila ada gangguan tenaga listrik, ganti rugi apabila terjadi pemadaman yang diakibatkan kesalahan/kelalaian pengoperasian pemegang izin usaha penyediaan tenaga listrik sesuai perjanjian jual beli tenaga listrik (Rahmita et al., 2017). Namun disisi lain, menurut Himawan \& Hutabarat (2021) putusan pengadilan sangat jarang mengabulkan gugatan semacam itu dengan alasan pemadaman listrik bukan hal yang disengaja atau merupakan kesalahan operasional dari pihak PLN sehingga tidak memenuhi termasuk dalam tindakan melawan hukum yang berakibat pada kerugian konsumen.

Berdasarkan uraian diatas, maka tujuan penelitian ini untuk mengungkap pengaturan perlindungan hukum konsumen pengguna listrik pada PT. PLN (Persero) UP3 serta upaya hukum yang dapat dilakukan oleh konsumen pengguna listrik apabila terjadi pemadaman listrik secara sepihak oleh PT. PLN Persero UP3 Bali Selatan.

\section{METODE PENELITIAN}

Metode yang digunakan dalam penelitian ini adalah metode penelitian empiris dengan pendekatan perundang-undangan dan pendekatan kasus. Dalam pengerjaannya, peneliti mengumpulkan informasi dengan wawancara dan menelaah dan menganalisa buku-buku hukum yang didasari peraturanperaturan hukum yang berlaku di Indonesia dengan mencari data melalui penelitian langsung kelapangan dan mengaitkan dengan buku ilmu hukum sesuai permasalahan yang diangkat serta mengaitkan dengan perundang-undangan yang berlaku saat ini. Sumber bahan hukum yang digunakan merupakan sumber primer yang diambil dari peraturan perundang-undangan dan sumber hukum primer dikumpulkan dari hasil penelitian terdahulu, maupun hasil karya dari kalangan hukum. Dengan demikian data dapat digabungkan dengan berbagai referensi buku hukum yang ter kait dan menghasilkan penelitian yang tidak melenceng dari hukum positif. (Saebani, 2008). Teknik analisis data dilakukan secara sistematis untuk menganalisa rumusan masalah.

\section{HASIL DAN PEMBAHASAN}

\section{Pengaturan Perlindungan Hukum Konsumen Pengguna Listrik Pada PT. PLN (Persero) UP3 Bali Selatan}

Dalam melakukan pekerjaan seseorang berhak mendapatkan kebebasan untuk berinovasi dan melakukan hal yang diinginkan namun sesuai dengan batasanya ,ada beberapa prinsip dalam melakukan pekerjaan:

1. Prinsip kebebasan merupakan prinsip dasar semua orang, teruntuk yang bekerja mau pun yang tidak bekerja. Segala aktivitas bebas dilakukan namun semua sesuai dengan etika dan tidak merugikan pihak lain. Dalam melakukan pekerjaan seorang bebas mengajukan pendapat, menyuarakan ketidaksetujuan akan putusan yang dibuat, semua biasa terjadi karena dengan perbedaan pemikiran membuat suatu perusahaan semakin solid.

2. Prinsip ketidaksetaraan, merupakan prinsip yang sudah terdoktrin pada beberapa orang khususnya dalam pekerjaan. Membeda-bedakan pergaulan sesuai dengan kasta atau materi. Hal seperti kadang membuat beberapa orang risih dan tidak jarang menjadi korban seperti rundung atau penindasan. Kedua prinsip ini saling berdampingan karena terjadi disetiap aktivitas yang dilakukan dan ada dilingkungan masing-masing orang.

Setiap hari terjadi dua hal yang saling berlawanan tersebut tinggal masing-masing individu yang bebas memilih prinsip yang digunakan dalam melakukan aktivitas sehari-hari termasuk dalam lingkungan sekitar. Perbedaan prinsip tersebut membuat negara Indonesia sampai saat ini belum maju karena masih banyaknya pihak yang memilih prinsip ketidaksetaraan yang secara tidak langsung melakukan perbuatan yang menguntungkan diri sendiri (Shidarta, 2006). 
Berkaca pada konsep di Negara Republik Indonesia menganut keadilan sosial. Kebanyakan masyarakat saat ini lebih aktif dengan keadilan sosial karena banyak yang lebih bertingkah laku tidak adil terutama dalam pembagian listrik kerumah-rumah. Tidak adil disini berarti tidak mematuhi peraturan atau hukum positif yang berlaku, contoh yang terjadi dan sudah banyak masyarakat yang perhatikan. Kasus pemadaman listrik yang membuat banyak masyarakat merasa kesal dengan perusahaan PLN namun jika lebih ditelusuri lagi banyak pihak pekerja khususnya pekerja lapangan yang dengan berbagai alasan tidak memberitahu masyarakat tentang pemadaman bergilir ini.

Berbicara soal perlindungan konsumen erat kaitannya dengan hak, bagaimana tidak jika seseorang tidak mendapatkan haknya maka seseorang termasuk tidak mendapatkan keadilan. Namun hak dapat didapat seseorang jika sudah melaksanakan kewajibannya dan secara langsung mempertanggungjawabkan kewajiban yang dilaksanakannya. Hak seorang sebagai konsumen tentunya berhak mendapatkan perlindungan dari pemerintah salah satu tindakan pemerintah dalam melindungi konsumen tentu dengan membuat undang-undang perlindungan konsumen. Tindakan represif dan preventif dilakukan demi mencegah terjadi hal yang tidak diinginkan dan tidak terjadi tindakan diluar hukum positif yang berlaku (Budiartha, 2016).

Berkaitan dengan perlindungan konsumen pihak PLN mengaku telah memprioritaskan listrik bagi masyarakat namun kejadian dilapangan berbeda dari pelayanan yang ada di PT. PLN. Wawancara dengan salah satu warga yang merasa dirugikan dengan pemadaman yang dilakukan PT. PLN (Persero) UP3 Bali Selatan adalah Bapak Rudi Arthana beralamat di Jl. Tukad Citarum, beliau mengatakan:

"tidak ada pemberitahuan apa apa tentang pemadaman listrik bergilir posisi saya memiliki balita dan butuh cahaya lampu, entah dari pihak kantornya yang tidak memberitahukan atau pekerja lapangan yang tidak meneruskan perintah atasannya" (Wawancara pada tanggal 20 Maret 2021).

Berkaitan dengan komentar negatif dari salah satu pelanggan PLN UP3 Bali Selatan penulis mewawancarai bapak Putu Agus Cipta Kusuma mengatakan:

"berkaitan dengan pemberitahuan kepada masyarakat terkait pemberitahuan pemadaman listrik kami selaku atasan sudah memberitahukan kepada karyawan agar tidak terjadi salah komunikasi dengan masyarakat terutama masyarakat yang ada dijalur Bali Selatan khususnya daerah panjer karena disana pusat perkantoran dan aktivitas masyarakat. Pemadaman sendiri dilakukan biasanya mulai pukul 09.00 sampai 15.00 itupun dilakukan sangat jarang guna menstabilkan arus listrik yang tersebar keberbagai wilayah di Bali Selatan. Kesalahan komunikasi dengan pekerja lapangan merupakan kesalahan dari pihak PLN dan kedepannya agar tidak terjadi kesalahan serupa demi kebaikan bersama." (Wawancara pada tanggal 20 Maret 2021).

Sebagai pelaku usaha, tentunya PLN berupa menghindarkan keluhan-keluhan dari pelanggan sebagai bentuk kewajiban mereka. Dengan menginformasikan rencana pemadaman yang akan dilakukan, diharapkan pelanggan akan memaklumi. Menurut Bapak Afriansyah selaku Supervisor Operasi UP3 Bali Selatan,

"Ketika pemadaman berlangsung, seringnya pelanggan yang komplain sekitar daerah kota, mungkin dari perbedaan latar belakang pendidikan dan karakteristik mereka, karena untuk warga pedesaan biasanya aka memaklumi pemadaman listrik. Banyak pelanggan kota yang mengeluh karena tidak dapat pemberitahuan dalam bentuk apapun, padahal sesuai surat yang keluar, surat tersebut sudah terkirim kekantor desa atau kelurahan masing -masing dan tidak hanya itu, kami juga sudah mengiklankan diradio dan menginformasikan melalui pesan seluler" (Wawancara pada tanggal 20 Maret 2021).

\section{Upaya Hukum yang dapat dilakukan oleh Konsumen Pengguna Listrik Apabila Terjadi Pemadaman Listrik Secara Sepihak oleh PT. PLN Persero UP3 Bali Selatan.}

Terjadinya pemadaman listrik secara sepihak oleh PT. PLN Persero UP3 Bali Selatan memang kesalahan perusahaan namun jika lebih ditelusuri terdapat kesalahan komunikasi terutama pada pekerja lapangan yang bertugas memberitahu pemadaman listrik bergilir pada masyarakat. Kesalahan kecil seperti ini menjadi besar karena banyaknya pihak yang merasa dirugikan terutama masyarakat pelaku konsumen. Masyarakat menuntut diberikan sanksi kepada PT. PLN Persero UP3 Bali Selatan agar tidak lagi melakukan kesalahan.

Sanksi sendiri memiliki makna dan arti yang berbeda-beda dan sesuai peraturan yang dibuat pemerintah. Penjabaran sanksi sebagai berikut (Hamzah, 1993). 
1. Sanksi Pidana

Merupakan sanksi yang paling memberikan efek jera diantara sanksi lainnya, hal ini ditunjukan dari hukuman yang diterima bervariasi seperti menetap dipenjara dan melakukan kegiatan yang ada dirumah tahanan selain itu memberikan buruk citra sendiri dan keluarga karena kedapatan melakukan perbuatan pidana.

2. Sanksi Perdata

Sanksi perdata biasanya melibatkan konflik antar masyarakat selaku konsumen dan perusahaan PLN sebagai perusahaan yang tidak memberitahukan pemadaman listrik kepada masyarakat hal ini membuat masyarakat meminta ganti rugi.

3. Sanksi Administratif

Sanksi ini berkaitan dengan pemerintahan semisal pelanggaran lalu lintas, akibat dari pada tidak membayar pajak dan masih banyak lagi pelanggaran yang membuat seseorang harus mengganti rugi pada negara karena kelalaiannya.

Dalam mempertanggungjawabkan kesalahan yang sampai membuat terjadinya kerugian pada masyarakat selaku konsumen pihak PLN PERSERO UP3 Bali Selatan sesuai dengan pengaturan pemerintah tentang perlindungan konsumen, harus mengganti kerugian yang diderita konsumen dan dalam kasus pemadaman listrik secara sepihak maka dituntut untuk mengganti rugi atas kesalahan yang dilakukan pekerja lapangan tersebut. Pemerintah sudah menghimbau berkali-kali tentang pemadaman listrik harus disampaikan terlebih dahulu kepada masyarakat karena jaman sekarang listrik sudah sebagai kebutuhan pokok yang menunjang produktivitas masyarakat dan guna meminimalisir kerugian konsumen yang berujung ganti rugi serta sanksi lain yang nantinya memberatkan pihak PLN PERSERO UP3 Bali Selatan. Terlebih terjadinya kesalahan yang dilakukan pihak PLN yang sampai membuat kerugian konsumen dapat membuat area perusahaan sendiri menjadi tercerna dan dapat mengurangi permintaan masyarakat terkait listrik berlangganan.

\section{SIMPULAN DAN SARAN}

\section{Simpulan}

Konsumen memiliki hak atas kenyamanan, keamanan, dan keselamatan dalam mengkonsumsi barang dan/atau jasa. Sementara dalam UU Ketenagalistrikan disebutkan bahwa konsumen berhak mendapatkan tenaga listrik secara terus menerus dengan mutu dan kendala yang baik. Maka sudah merupakan kewajiban PT. PLN (Persero) UP3 Bali Selatan sebagai pemegang izin usaha penyediaan tenaga listrik, untuk menyediakan tenaga listrik yang memenuhi standar mutu dan kendala yang berlaku. Apabila pemadaman listrik yang terjadi kurang dari standar pelayanan yang telah ditetapkan oleh Pemerintah, konsumen berhak mendapat ganti rugi. Adapun upaya yang dapat dilakukan konsumen apabila terjadi pemadaman listrik sepihak oleh PT. PLN (Persero) adalah dengan memberikan pengaduan kepada PT. PLN (Persero). Namun bila hasil upaya awal tersebut dirasa masih kurang memuaskan, konsumen dapat mengambil upaya hukum yakni penyelesaian sengketa melalui pengadilan atau diluar pengadilan berdasarkan pilihan sukarela para pihak yang bersengketa.

\section{Saran}

Untuk masyarakat luas, sebagai konsumen listrik masyarakat seharusnya menjadi konsumen cerdas yang mengetahui hak-hak dan kewajiban-kewajibannya. Sehingga saat terjadi pemadaman listrik sepihak oleh PT. PLN (Persero), konsumen listrik tidak hanya diam dan seolah-olah terbiasa akan pemadaman listrik yang sering terjadi, namun dapat melakukan pengaduan dan menuntut hak kompensasi kepada PT. PLN (Persero) UP3 Bali Selatan. Untuk PT. PLN Persero) UP3 Bali Selatan, sebagai produsen listrik seharusnya selalu meningkatkan pelayanan dan dapat menjaga kepercayaan konsumen listrik. Salah satunya adalah dengan tidak sering melakukan pemadaman listrik. Apabila memang harus memadamkan listrik, PT. PLN (Persero) UP3 Bali Selatan seharusnya memberikan informasi terlebih dahulu kepada konsumen listrik, sehingga konsumen listrik dapat mempersiapkan keadaan listrik padam dan tidak terlalu mengganggu aktifitas konsumen. Standar mutu pelayanan yang ditetapkan bersama Menteri ESDM seharusnya juga dapat diinformasikan kepada konsumen secara luas, sehingga tidak terkesan PT. PLN (Persero) tertutup informasi dan baru memberikan informasi bila ditanya oleh konsumen. 


\section{DAFTAR PUSTAKA}

Abdullah, J. (2010). Aspek Hukum dalam Bisnis. Nora Media Enterprise, Kudus.

Andrea, G. P. (2016). Perlindungan Konsumen dalam Pemadaman Listrik Sepihak oleh PT. PLN (Persero). Jurnal Lex Crimen, 5(6), 23-31.

Ardiyati, S., \& Hartono, K. (2019). Perlindungan Konsumen Terhadap Pemadaman Listrik Sepihak oleh PT. PLN Menurut Undang-undang Nomor 8 Tahun 1999 (Studi Kasus di Kota Semarang). Konferensi Ilmiah Mahasiswa Unissula (KIMU) 2.

Budiartha, I. N. P. (2016). HUKUM OUTSOURCING: Konsep Alih Daya, Bentuk Perlindungan, dan Kepastian Hukum. Setara Press, Malang.

Hamzah, A. (1993). Sistem Pidana dan Pemidanaan Indonesia. Pradnya Paramita, Jakarta.

Himawan, C., \& Hutabarat, S. M. D. (2021). Perlindungan Bagi Konsumen Pengguna Listrik Akibat Pemadaman Tanpa Pemberitahuan Di Wilayah Jawa Barat. Widya Yuridika: Jurnal Hukum, 4(1), 93-108.

Nasution, A. (1999). Hukum Perlindungan Konsumen. Daya Widya, Jakarta.

Rahmita, Firdaus, \& Hasanah, U. (2017). Perlindungan Hukum Konsumen terhadap Pemadaman Listrik oleh PT. PLN (Persero) Sub. Rayon Pulau Kijang (Studi Kasus Pemadaman Listrik Sepihak di Kecamatan Reteh Kabupaten Indragiri Hilir). Jurnal Online Mahasiswa Fakultas Hukum, 4(2), 1-10.

Saebani, B. A. (2008). Beni ahmad saebani. Pustaka Setia, Bandung.

Shidarta. (2006). Hukum perlindungan konsumen Indonesia. Grasindo, Jakarta. 